Article

\title{
Influence of Arc Brazing Parameters on Microstructure and Joint Properties of Electro-Galvanized Steel
}

\author{
Soon Jae Lee ${ }^{1} \mathbb{D}$, Ashutosh Sharma ${ }^{2} \mathbb{D}$, Do Hyun Jung ${ }^{1}$ and Jae Pil Jung ${ }^{1, *}$ \\ 1 Department of Materials Science and Engineering, University of Seoul, Seoul 02504, Korea; \\ aolofinj@usc.edu.au (S.J.L.); jdh1016@uos.ac.kr (D.H.J.) \\ 2 Department of Materials Science and Engineering and Department of Energy Systems Research, \\ Ajou University, Suwon 16499, Korea; ashu.materials@gmail.com \\ * Correspondence: jpjung@uos.ac.kr; Tel.: +82-2-6490-2408
}

Received: 12 August 2019; Accepted: 9 September 2019; Published: 12 September 2019

\begin{abstract}
Arc brazing of zinc-coated steel (EG, Electro-galvanized steel) using Cu-3 wt $\%$ Si filler metal was performed. The influence of arc current and brazing speed on the bonding properties of the joint, such as bead characteristics, arc penetration, joint hardness, and tensile shear strength were evaluated. The microstructural characteristics of the joint were examined by scanning electron microscopy (SEM) and the compositional information was revealed by energy dispersive spectroscopy (EDS). The throat thickness varies inversely with the brazing speed. The EG joint shows the formation of $\mathrm{Fe}_{2} \mathrm{Si}$ phases, which result in higher microhardness than the base metal. The tensile samples were fractured in base metal, while minor bead cracks developed in the samples brazed at $80 \mathrm{~cm} / \mathrm{min}-80 \mathrm{~A}, 60 \mathrm{~cm} / \mathrm{min}-70 \mathrm{~A}$, $70 \mathrm{~cm} / \mathrm{min}-70 \mathrm{~A}$.
\end{abstract}

Keywords: gas metal arc brazing; zinc-coated steel; filler metal; tensile shear strength; microhardness

\section{Introduction}

The automotive industry always demands high reliability of its auto components to meet safety requirements. Various joints in automotive body parts, such as rooftops, hood, and car door frame are important parts requiring high reliability [1-6]. For joining steel sheets, fusion welding, friction, spot and laser welding have been used $[7,8]$. These joining methods are applied to automotive parts depending on their particular application and needs such as lightweight, high durability and corrosion resistance. However, these welding methods have several drawbacks, such as pore, spatter, flux residue, and corrosion after joining [7-10].

Gas metal arc (GMA) process is the most popular metal joining method using arc with a shielding gas due to its various advantages such as good weld penetration, reasonable brazing speed, less slag, etc., [11-13]. However, GMA brazing requires the optimization of various operating parameters, such as arc speed, arc current, filler feeding rate, shielding gas rate, etc. [13]. Among all these, heat input is regarded as the most important parameter that is related to arc current, voltage, and speed. For example, lower heat input results in a defect like insufficient weld penetration and unstable bead shape, while higher heat input degrades the base metals [14]. Therefore, the combination of arc current and brazing speed needs to be optimal for a promising brazed joint performance [14,15]. Meanwhile, zinc vaporization occurs from the $\mathrm{Zn}$-coated steel (base metal) during arc welding processes because the melting temperature $\left(460^{\circ} \mathrm{C}\right)$ and vaporization temperature $\left(906^{\circ} \mathrm{C}\right)$ of $\mathrm{Zn}$ are lower than those of arc welding and arc brazing [16].

Therefore, in these welding processes, to control the heat input, cooling rate, and the joint gap is important to reduce zinc vaporization and defects [16-18]. Compared to previous studies, most of 
the joining of $\mathrm{Zn}$-coated steels were performed by using laser/arc or hybrid laser welding using $\mathrm{Cu}-\mathrm{Si}$ filler. Our study reports a comprehensive study of arc brazing of advanced electro-galvanized steels (EG), its characteristics, properties and optimization of arc brazing current and speed for optimum joint reliability. A combination of brazing current and speed is required to obtain a strong and smooth brazed joint. Further, most of the studies are related to GI or GA steels, while studies related to EG steels brazing are limited in the literature. In this study, GMA brazing was performed on the Zn-coated steel sheets, and the brazing performance was studied through the investigation of bead appearance, microstructure, tensile shear test, throat thickness, and penetration width and depth.

\section{Experimental Procedures}

\subsection{Materials}

The base metal was an EG steel sheet $(100 \mathrm{~mm} \times 200 \mathrm{~mm} \times 0.7 \mathrm{~mm})$ provided by the POSCO Steel, Pohang, Korea. The thickness of the zinc-coated layer is approximately $3 \mu \mathrm{m}$. The filler used for the GMA process was CuSi-3 rod. The detailed composition of base metal and filler metal (Cu-3 wt \%Si brazing filler) are listed in Table 1.

Table 1. The composition (in wt \%) of the base metal and filler metal.

\begin{tabular}{cccccccccc}
\hline $\begin{array}{c}\text { Joining } \\
\text { Components }\end{array}$ & Fe & Cu & Si & Mn & Pb & Zn & S & P & C \\
\hline Base Metal & Bal. & - & 0.25 & 0.45 & - & - & 0.046 & 0.042 & 0.18 \\
Filler Metal & 0.03 & Bal. & 2.94 & 0.85 & 0.003 & 0.01 & - & - & - \\
\hline
\end{tabular}

\subsection{Arc Brazing Process}

Figure 1 shows the GMA equipment (Daihen DP 350, OTC Daihen Asia Co., Ltd., Pathum Thani, Thailand). The various parts are shown to consist of a current-voltage controller, wire feeder and arc generator. The specimen was mounted on the brazing table and fixed by magnetic jigs. Argon (shielding gas) with $99.99 \%$ purity was blown at $20 \mathrm{~L} / \mathrm{min}$ rate. The Ar gas and brazing filler wire were fed by the automatic system during the brazing process.
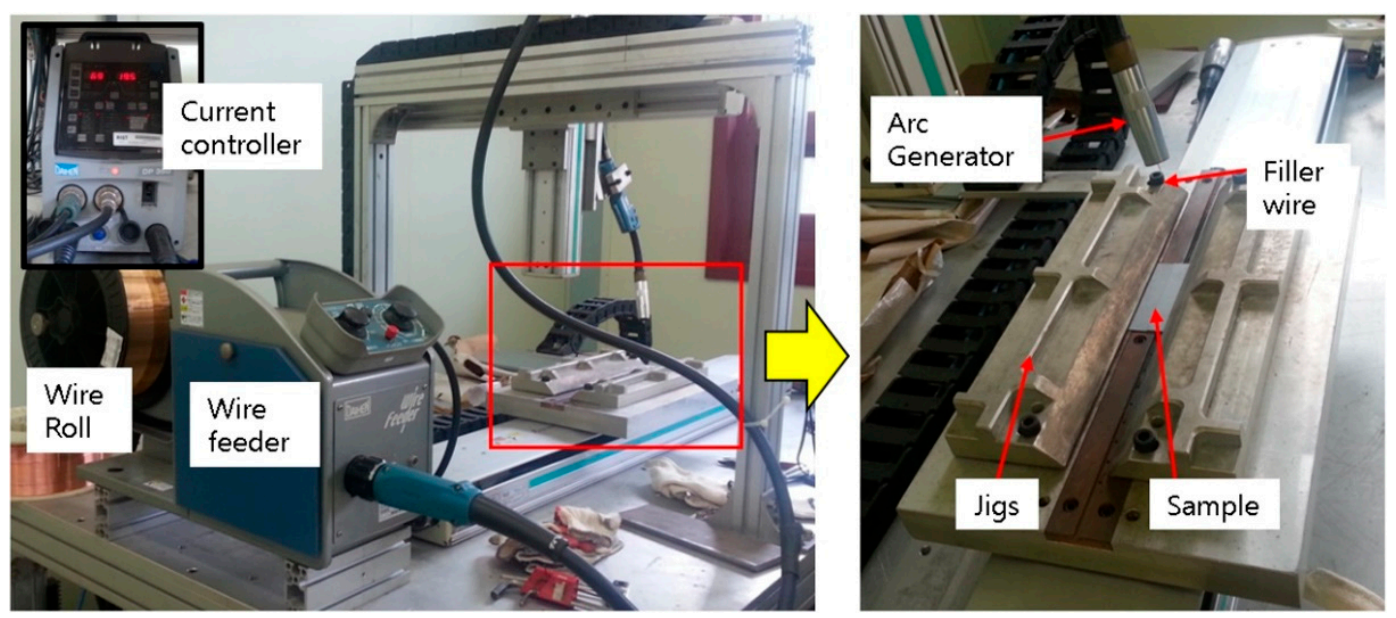

Figure 1. Arc brazing equipment and setup.

The arc voltage was 19.3-19.8 V and the length of the overlap joint in brazing specimen was $10 \mathrm{~mm}$. There are two sets of variables studied for brazing, (1) arc current (50-80 A) and (2) arc travel 
speed (brazing speed) of $60-90 \mathrm{~cm} / \mathrm{min}$, respectively. The heat input $Q(\mathrm{~kJ} / \mathrm{mm})$ can be calculated from the Equation (1) [19]:

$$
Q=\frac{60 \times k \times V \times I}{1000 \times v}
$$

where, $V$ and $I$ are arc voltage $(\mathrm{V})$ and arc current $(\mathrm{I}) ; v$ is the arc brazing speed $(\mathrm{mm} / \mathrm{min})$, and $k$ is the thermal efficiency $=0.9$ (for GMA brazing).

\subsection{Sample Preparation and Analysis}

After the GMA brazing, the brazing specimens were cross-sectioned and epoxy mounted. The specimens were further ground with \#500, \#1200, \#2400, \#4000 sandpapers and polished with a diamond paste having $1 \mu \mathrm{m}$ powder size. The specimens were etched with acid solutions of $10 \% \mathrm{HNO}_{3}$ and $10 \%$ $\mathrm{HCl}$ for $10 \mathrm{~s}$. The microstructure of the cross-sectioned brazing joint was observed by scanning electron microscope (SEM, JEOL JSM-6480, JEOL, Tokyo, Japan), and its chemical composition was analyzed by energy dispersive spectroscopy (EDS, Oxford Instruments, Abingdon, UK). The penetration depth and width of the fusion zone was calculated and studied with various arc current and speed.

\subsection{Mechanical Properties of Joint}

\subsubsection{Microhardness}

The microhardness was measured over 6 sections across the brazed joint depending upon the heat-affected zones (HAZ). The various sections, as shown in Figure 2, are parts of HAZ across the cross-section of the joint. Zone 1 is the filler portion, Zone 2 corresponds to the EG steel part near to the joint. Zone 3, Zone 4 and Zone 5 lie well ahead of the Zone 2. Zone 6 consists of the gap between the two-lap joints. $X Y$ shows the vertical line across joint cross-section for microhardness measurement. The hardness measurements were done using a hardness tester (Mitutoyo MVK H1) at a load of $100 \mathrm{gf}$ and holding time of $15 \mathrm{~s}$. The Vickers hardness is calculated as follows:

$$
\text { Hardness }(\mathrm{Hv})=1.854 \times\left(\frac{F}{d^{2}}\right)
$$

where $F$ is the load (kgf) and $d$ is the average of the indentation diameter (mm).

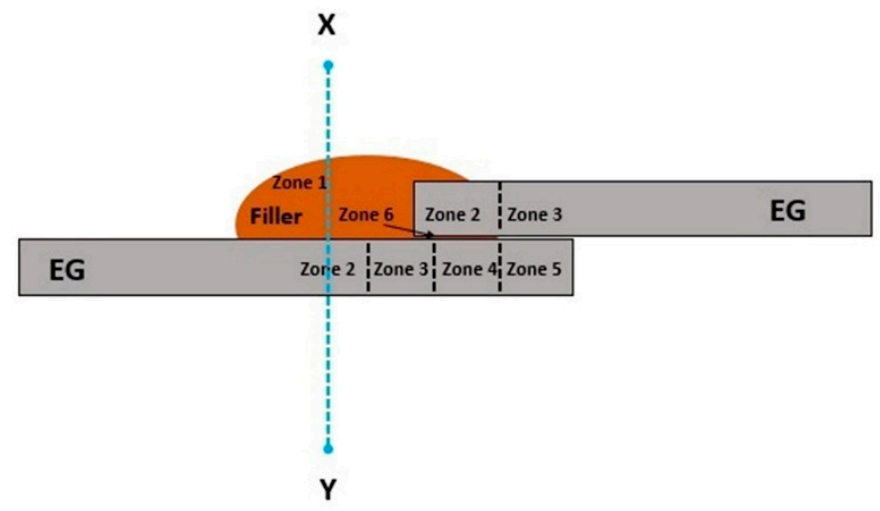

Figure 2. Microhardness measurement across the lap joint in various heat-affected zones (HAZs). XY shows the line profile for the hardness measurement.

\subsubsection{Tensile Shear Test}

The tensile shear test was studied with a tensile testing machine (UTM, MTS 810, MTS, Eden Prairie, MN, USA) according to the Japanese standards reported in Refs [20-22]. The test samples were of $100 \mathrm{~mm}$ in length, $20 \mathrm{~mm}$ width, $0.7 \mathrm{~mm}$ thickness and $10 \mathrm{~mm}$ lap length. The strain rate was fixed to $0.001 / \mathrm{s}$. The schematic of the tensile specimen used for shear is shown in Figure 3. 


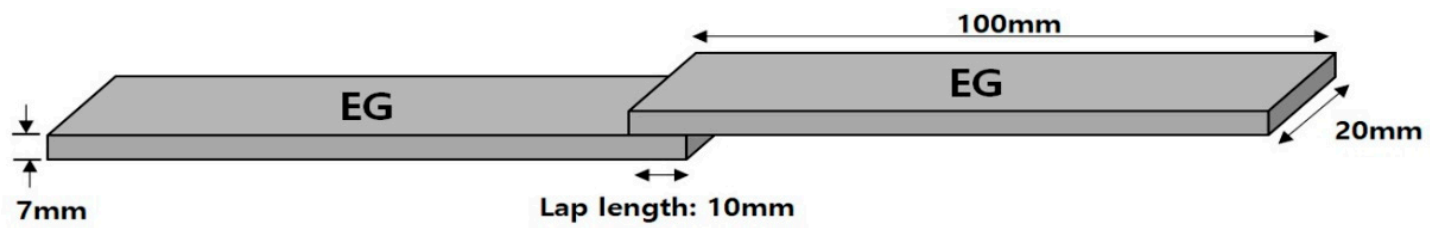

Figure 3. Sample dimensions for the tensile shear test.

\section{Results and Discussions}

\subsection{Bead Characteristics}

Figure $4 \mathrm{a}$ demonstrates the difference of bead surface with an arc current of 50,60, 70 and $80 \mathrm{~A}$ at a fixed arc speed of $80 \mathrm{~cm} / \mathrm{min}$. Initially, the bead appearance was darker at 50-60 A. When the arc current reached $70 \mathrm{~A}$, bead appearance was brighter with few instances of spattering. The bright color indicates smooth and clear joint surface. Further increases in arc current to 80 A shows even darker bead surface. Spattering occurs under many factors, such as an unstable arc, and/or unclean joint surface due to inadequate current/voltage supply, etc. $[23,24]$. The severe melting occurs at high current due to high input according to Equation (1).

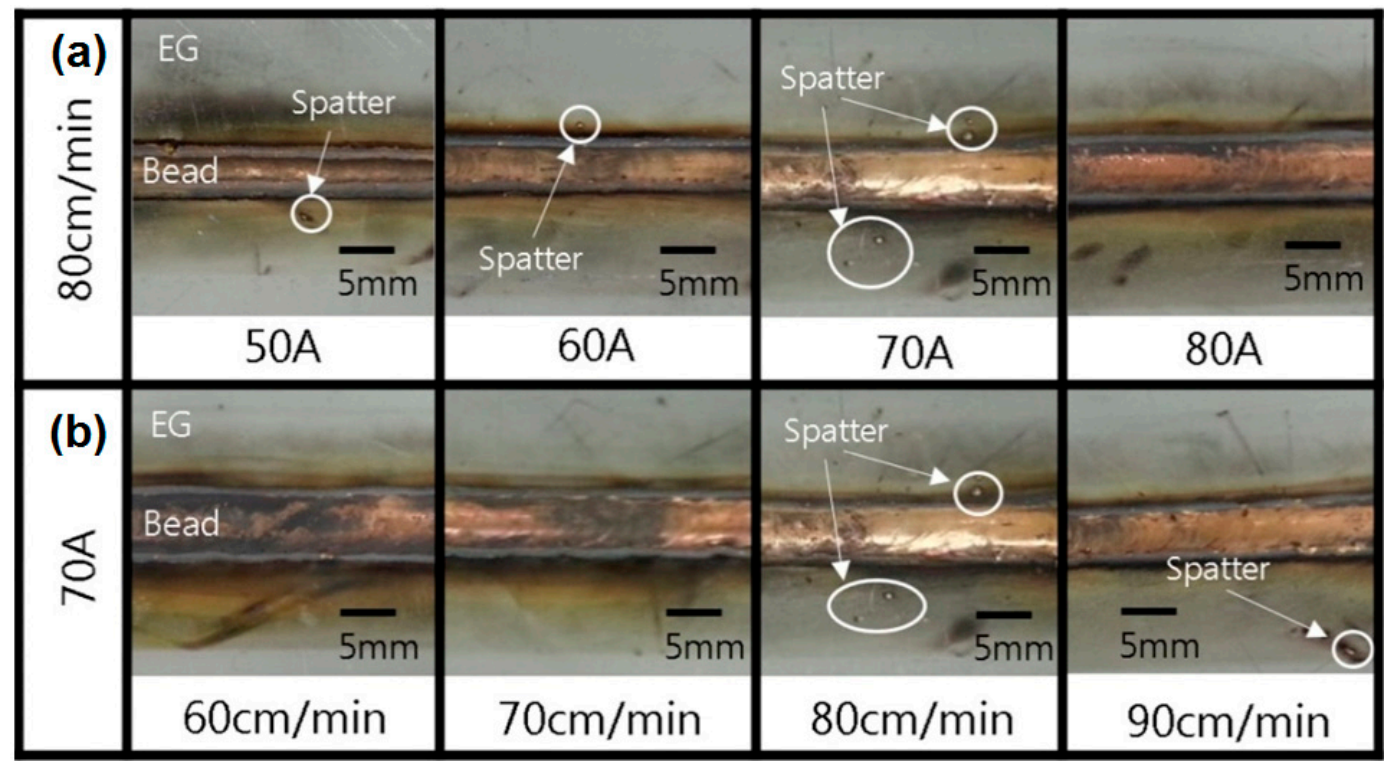

Figure 4. Bead appearance. (a) arc current (at $80 \mathrm{~cm} / \mathrm{min}$ ), and (b) brazing speed (at $70 \mathrm{~A}$ ).

Schmidt et al. attributed this observation as a common concern in the welding of hot-dip galvanized steels [25]. Kimura and his co-workers reported that the reason for bead imperfections are due to zinc evaporation and propagation through the liquid filler metal [26].

Figure $4 \mathrm{~b}$ shows the difference of bead face at various arc speeds for the constant arc current of $70 \mathrm{~A}$. When the brazing speed was low, i.e., 60 to $70 \mathrm{~cm} / \mathrm{min}$, then the bead appeared dark covered with black residues. However, $80 \mathrm{~cm} / \mathrm{min}$ of arc speed condition gave a bright and shiny color. In addition, faster brazing speed $(90 \mathrm{~cm} / \mathrm{min})$ also produced dark beads. It is to be noted that heat input varies inversely with brazing speed. High heat input induces rapid melting and hence burnt out beads at low brazing speeds [14]. The optimum bead surface was obtained at $80 \mathrm{~cm} / \mathrm{min}$.

These findings of bead imperfections such as spattering and width irregularities have been verified by various researchers in the past but the detailed formation of bead characteristics is not available yet. Various types of zinc-coated steels play a role in laser welding but have not yet been researched for arc brazing in detail [27]. 


\subsection{Bead Width}

As already discussed, to stabilize the process monitoring and control of bead imperfections, we examined the bead width developed during the application of various brazing current and speed which controls the heat input and power. Figure 5a shows that the bead face width increases from 3.9 to $7.5 \mathrm{~mm}$ with the arc current from 50 to $70 \mathrm{~A}$ (at $80 \mathrm{~cm} / \mathrm{min}$ ). As already pointed out, this may be related to a high heat input which causes rapid fusion of base metal and $\mathrm{Cu}$-Si filler producing thick $\mathrm{Fe}-\mathrm{Si}$ intermetallic compounds (IMCs). Above $70 \mathrm{~A}$, the bead width reduces slightly to $6.9 \mathrm{~mm}$ and remains stable.
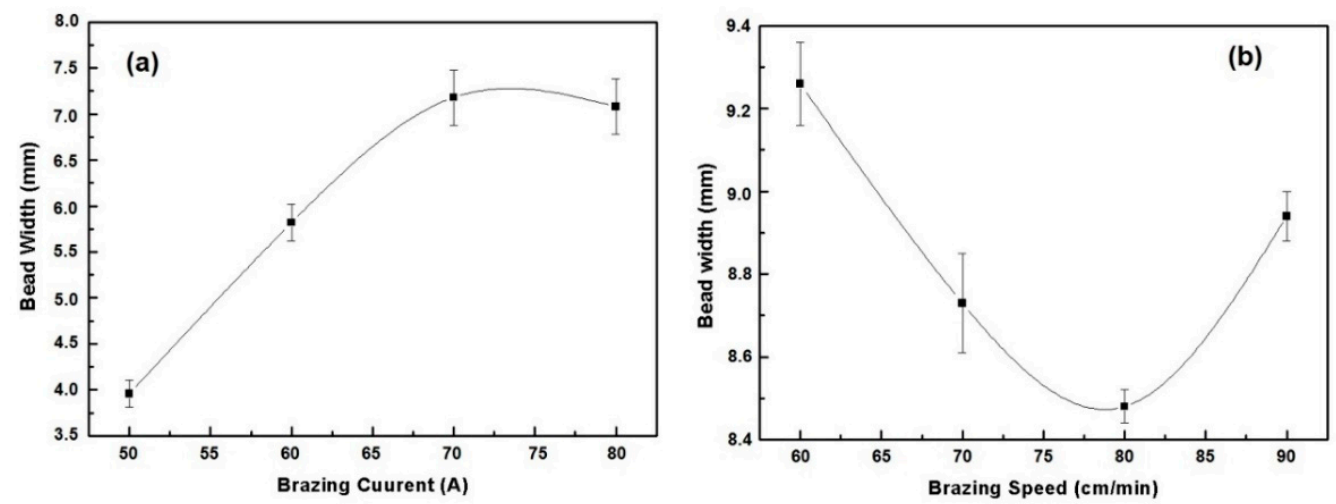

Figure 5. Bead face width as a function of (a) arc current (at $80 \mathrm{~cm} / \mathrm{min})$, and (b) arc speed (at 70A).

Figure $5 \mathrm{~b}$ shows that the bead face width reduces with brazing speed from 60 to $80 \mathrm{~cm} / \mathrm{min}$ (arc current of $70 \mathrm{~A}$ ). The bead width increases at $90 \mathrm{~cm} / \mathrm{min}$ due to the turbulence experienced by arc flow at extremely high speeds. It is also noticed from Figure $5 a, b$ that the difference of bead width at different arc current is approximately $>1 \mathrm{~mm}$, and the smallest bead width is approximately $\approx 4 \mathrm{~mm}$. On the other hand, the difference of bead width at different brazing speeds is $<<1 \mathrm{~mm}$ and the smallest bead width is approximately $8.5 \mathrm{~mm}$. It shows that arc current is a more important factor than brazing speed to control the bead width [14,28].

\subsection{Penetration Depth and Width}

Figure 6a shows the cross-sectional SEM image of bead showing fused zone with penetration width and depth at an arc current of $70 \mathrm{~A} / 80 \mathrm{~cm} / \mathrm{min}$. The base metal is slightly damaged during GMA brazing due to the arc pool at high temperature. Therefore, proper arc current and speed are necessary even if the brazing temperature is over than the melting temperature of the base metal. The melting of base metal and filler creates a fusion zone, having a penetration depth and width.
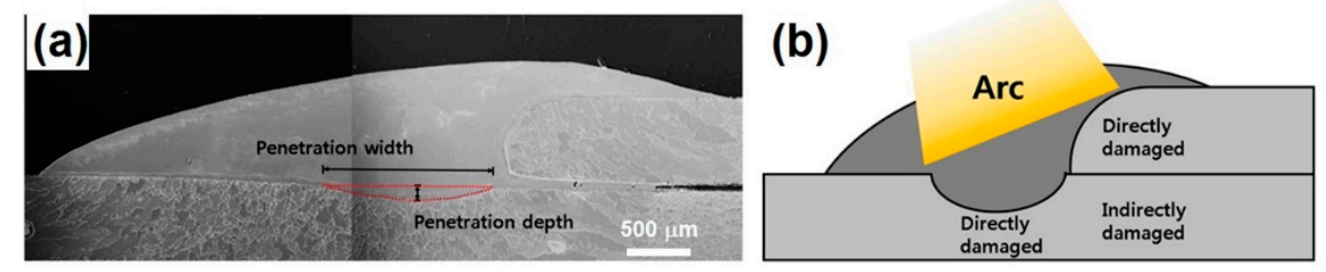

Figure 6. (a) Measurement of penetration width and depth, (b) Schematic showing damaged zones.

Figure $6 \mathrm{~b}$ shows a schematic diagram to explain the damage to the base metals. Two types of damaged parts can be seen: the upper and lower side of the base metal, which are affected directly and indirectly by the arc. Normally, bead penetration occurs on the bottom side in a lap joint because of the HAZ with arc pool [17]. 
Figure 7a shows the penetration depth and width increase with arc current except at $70 \mathrm{~A}$ due to progressive fusion of $\mathrm{Cu}$-Si filler with the EG steel. The penetration depth and width are maximum at 80 A. Lesser penetration indicates less amount of heat energy and vice versa.
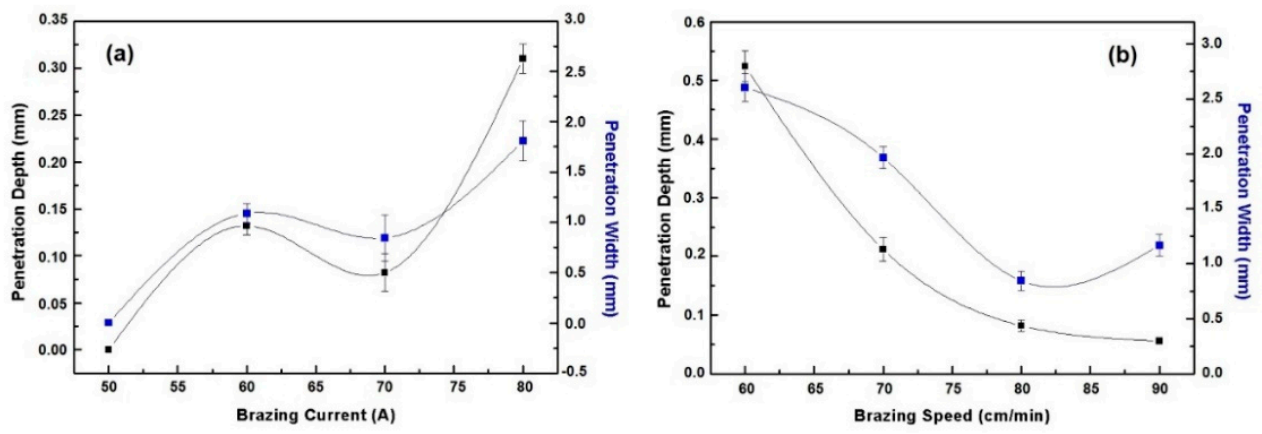

Figure 7. The variation of penetration depth and width with (a) arc current (at $80 \mathrm{~cm} / \mathrm{min}$ ) and (b) speed (at $70 \mathrm{~A})$.

Figure $7 \mathrm{~b}$ shows a significant decrease in the penetration depth and width, especially penetration depth decrease is more than width. As discussed, the penetration is related to the heat input amount according to the Equation (1). The brazing speed varies inversely to the heat input. The heat input is tremendous at lower brazing speeds, and overheating causes severe penetration. Base metal's thermal diffusivity is the most important for penetration sensitivity because of cooling rate. Further decrease in penetration depth at $90 \mathrm{~cm} / \mathrm{min}$ with an increase in width is caused by a lesser fusion of filler with base metals and unstable arc flow.

Thermal diffusivity $\left(D\right.$ in $\mathrm{m}^{2} / \mathrm{s}$ ) is proportional to base metal characteristics, such as thermal conductivity $(k)$ and inversely proportional to thermal capacity $(c)$ according to Equation (3).

$$
D=\frac{k}{\rho c}
$$

where, $k=$ thermal conductivity $(\mathrm{W} /(\mathrm{m} \cdot \mathrm{K})), \rho=$ density $\left(\mathrm{kg} / \mathrm{m}^{3}\right)$ and $c=$ specific heat capacity $(\mathrm{J} /(\mathrm{kg} \cdot \mathrm{K})$. According to Equation (3), the penetration value can be controlled by base metal selection. Due to the high vapor pressure of the zinc-coated on steels, plasma formation may occur and affects the absorption of arc energy. The maximum vapor pressure can rise up to $120 \mathrm{MPa}$ around $\approx 2600{ }^{\circ} \mathrm{C}$. The viscosity of iron at such a high temperature is given by relation:

$$
\eta=\eta_{0} \mathrm{e}^{\frac{E}{R T}}
$$

Here, $\mathrm{R}$ is the gas constant, $E$ is the temperature coefficient of viscosity, and $\eta_{0}$ is the initial viscosity. According to equation (4), $\eta \approx 4 \times 10^{-3} \mathrm{~kg} \cdot \mathrm{m} / \mathrm{s}$. As a result, the spattering and porosity rise but penetration reduces and bead discontinuity increases at high brazing speeds [14].

\subsection{Microstructural Analysis of Joint}

The microstructure of bead joint was examined at optimal penetration width and depth observed at arc brazing condition of $70 \mathrm{~A}-80 \mathrm{~cm} / \mathrm{min}$. Figure $8 \mathrm{a}-\mathrm{d}$ shows the microstructure of the joint, fusion zone and the various Fe-Si IMCs identified by the EDS analysis (Figure 8e-h). The Gibbs free energy of various Fe-Si reaction compounds is shown in Table 2. 


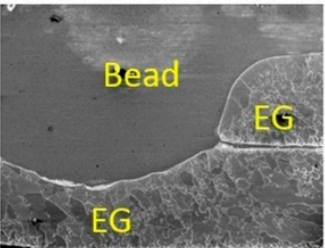

(a)

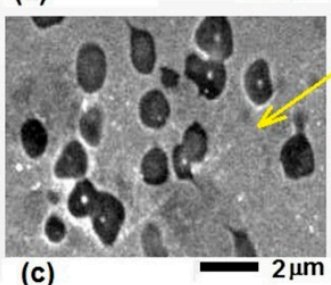

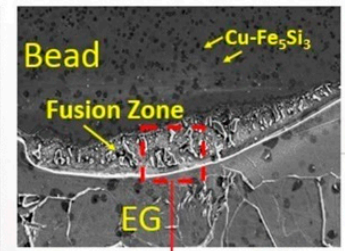

(b)

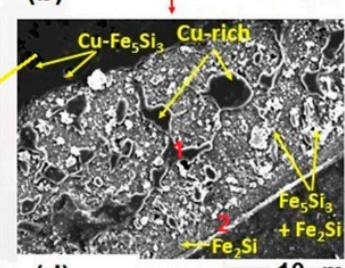

(d)
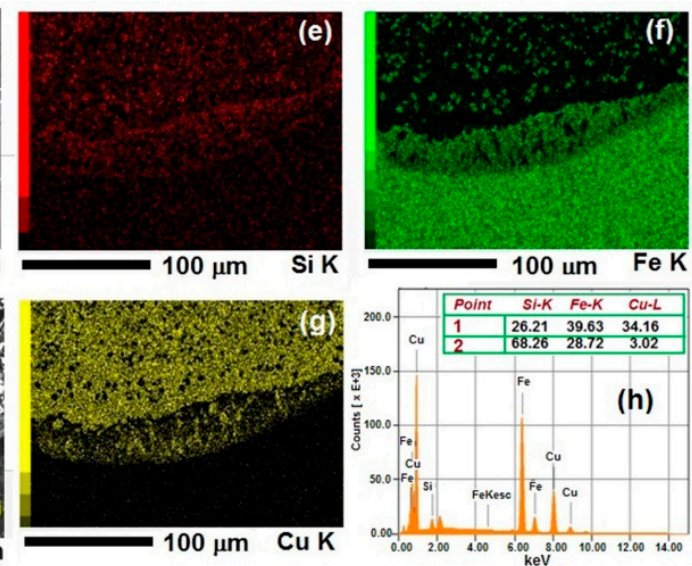

Figure 8. The microstructure of the bead cross-section and its composition. (a) The SEM image of lap joint, (b) the fusion zone, (c) the morphology of flower structure $\mathrm{CuFe}_{5} \mathrm{Si}_{3}$, (d) high-resolution image of fusion zone. (e-g) elemental maps of $\mathrm{Si}, \mathrm{Fe}$, and $\mathrm{Cu}$ obtained from SEM image of (b), (h) the EDS spectrum of (d). The atomic percent values are given in the table.

Table 2. Gibbs free energy of various Fe-Si compounds [14].

\begin{tabular}{ccc}
\hline S.No. & Reaction & $\Delta G \mathbf{( k J / m o l )}$ \\
\hline 1 & $\mathrm{Fe}_{2} \mathrm{Si}+\mathrm{Si} \rightarrow \mathrm{Fe}_{5} \mathrm{Si}_{3}$ & -285.2 \\
2 & $\mathrm{Fe}_{2} \mathrm{Si}+3 \mathrm{Si} \rightarrow 2 \mathrm{FeSi}_{2}$ & -29.42 \\
3 & $\mathrm{Fe}_{5} \mathrm{Si}_{3}+7 \mathrm{Si} \rightarrow 5 \mathrm{FeSi}_{2}$ & -30.6 \\
4 & $\mathrm{Fe}_{5} \mathrm{Si}_{3}+\mathrm{Fe} \rightarrow 3 \mathrm{Fe}_{2} \mathrm{Si}$ & -104.68 \\
\hline
\end{tabular}

According to Sharma et al. there are various possibilities of Fe-Si compounds according to the Gibbs thermodynamics between Fe-Si reactions, such as the $\mathrm{Fe}_{5} \mathrm{Si}_{3}$ and $\mathrm{Fe}_{2} \mathrm{Si}$ and the $\mathrm{Fe}_{5} \mathrm{Si}_{3}$ (Reactions 1-4, Table 2). Out of these, $\mathrm{Fe}_{5} \mathrm{Si}_{3}$ is the primary phase in $\mathrm{Zn}$-coated steel as expected using $\mathrm{Cu}$-Si based filler [14]. It is a noteworthy point to mention that $\mathrm{Cu}$ is randomly present surrounding $\mathrm{FeSi3}$ phases via liquid phase separation around $\approx 1100{ }^{\circ} \mathrm{C}$. Therefore, the final phase designated inside the weld is Fe5Si3(Cu) [29-32].

The filler metal area contains scattered flower petals like particles $\left(\mathrm{Fe}_{5} \mathrm{Si}_{3}\right)$ [30,31]. In addition, at the base metal side (EG) has high Fe concentration and low Si concentration. The filler metal side includes Fe compound (Figure $9 \mathrm{e}-\mathrm{h}$ ) while the base metal side does not contain $\mathrm{Cu}$. Fusion zone is the copper matrix reinforced with $\mathrm{Fe}_{5} \mathrm{Si}_{3}$ generates at higher arc current and speed, i.e., $(80 \mathrm{~A}-80 \mathrm{~cm} / \mathrm{min}$ ). This may be attributed to the higher current and speed, the melting and solidification are rapid, and arc and liquid metal flow are turbulent. The EDS mapping analysis shows the atomic ratios identified in different regions are approximately $\sim 5: 3$ and $\sim 1: 2$ as shown in Figure $8 \mathrm{~h}$. This confirms the presence of two $\mathrm{Fe}-\mathrm{Si}$ compounds, $\mathrm{Fe}_{5} \mathrm{Si}_{3}$, and $\mathrm{Fe}_{2} \mathrm{Si}$ as expected in a matrix of $\mathrm{Cu}$. Therefore, rapid segregation of $\mathrm{Fe}_{5} \mathrm{Si}_{3} \mathrm{Cu}$ particles is established in the bead zone and grows there. These segregated compounds grow into spherical form by an Ostwald ripening mechanism to reduce their surface energy. 


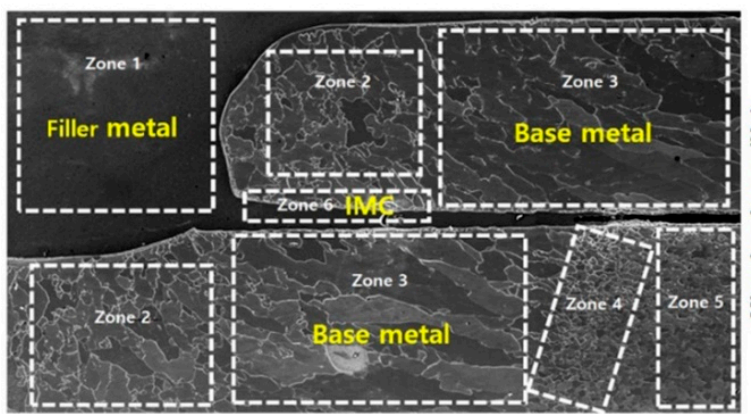

(a)

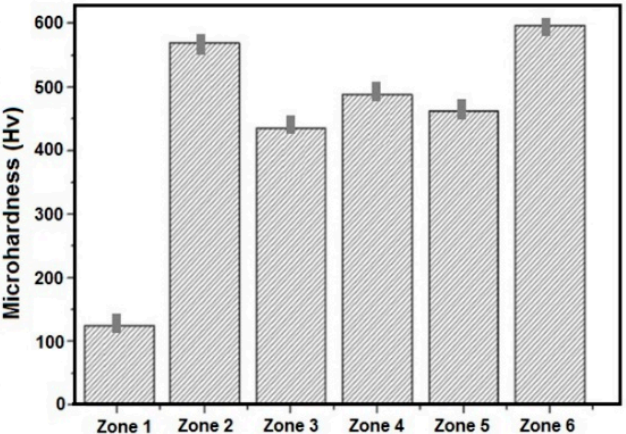

(b)

Figure 9. (a) The section for microhardness measurements. (b) Microhardness of the cross-section $(80 \mathrm{~cm} / \mathrm{min}, 70 \mathrm{~A})$.

\subsection{Joint Mechanical Properties}

\subsubsection{Microhardness}

Figure 9a shows the cross-section of the various zones in the bead and corresponding hardness values are plotted in Figure 9b. Zone 1 represents the filler metal area and has the lowest microhardness around $122.6 \mathrm{Hv}$. The microhardness values of Zone 2 and 6 are almost same and maximum (around $596.6 \mathrm{Hv}$ ). These Zones 6 and 2 are under direct contact to the laser beam and fused with the filler metal. Zone 6 has the maximum hardness of $596.6 \mathrm{Hv}$ due to the reinforcement of $\mathrm{Fe}_{5} \mathrm{Si}_{3}$ with $\mathrm{Cu}$ of the filler metal. This can be also related to the finer grains brought about by the composite effect of $\mathrm{CuFe}_{5} \mathrm{Si}_{3}$ compounds. Other Zone 3, 4, and 5 have microhardness varying from 435.4 to $488.2 \mathrm{Hv}$ (Figure 9b). The hardness of Zone 3 is slightly higher than Zone 2 and 6 . This is already clear from the bigger grains as shown in Figure 9a. Zone 4 and 5 have similar microhardness as they are away from the fusion zone.

The various zones are the parts of HAZ across the cross-section line of the joint. As shown in Figure $9 \mathrm{a}$, the recrystallized grains are present in the base metal. The microstructure of the base metal consists of a mixed coarse and fine grains. The coarse grains show the process of ongoing grain growth during the joining. While the filler metal shows relatively smaller grains than that in the base metal.

Zone 1 is the filler itself while Zone 2 is the EG steel portion near the joint. Zone 3, Zone 4 and Zone 5 lie in the same line away from the joint (Zone 2). Zone 6 is the gap between the two EG steel laps. As shown in Figure 9a, Zone 2 has the fine grains while Zone 3 has a large-grained structure, the grain size of Zone 3 is bigger than that of Zone 2. In addition, Zone 4, and 5 have the smallest grain size because of the typical HAZs. Generally, the smaller grain has a harder microhardness value. The microhardness of Zone 2 and 6 are highest because of the additional hardening contribution coming from the reinforcement of hard $\mathrm{Fe}_{5} \mathrm{Si}_{3}$ particles into the base metal during fusion. In addition, the more Si component is contained in Zone 2 because it is close to the filler metal. It means Zone 2 has more Fe-Si compound than Zone 4. According to these results, Fe-Si compound is related to microhardness increase, and it is more influential than grain size effect towards hardness [14].

\subsubsection{Joint Tensile Shear}

Figure 10a displays the post-test photographs tensile shear fractured samples. All the samples after tensile shear testing were fractured at the base metal. The bead thickness (few $\mathrm{mm}$ ) is too thick compared to the base metal thickness $(\approx 0.7 \mathrm{~mm})$. Tensile shear strength results indicate the base metal strength. Some cracks are also found in the beads $(80 \mathrm{~cm} / \mathrm{min}-80 \mathrm{~A}, 60 \mathrm{~cm} / \mathrm{min}-70 \mathrm{~A}, 70 \mathrm{~cm} / \mathrm{min}-70 \mathrm{~A})$. Figure $10 \mathrm{~b}$ depicts the tensile shear testing results of the different investigated samples. 


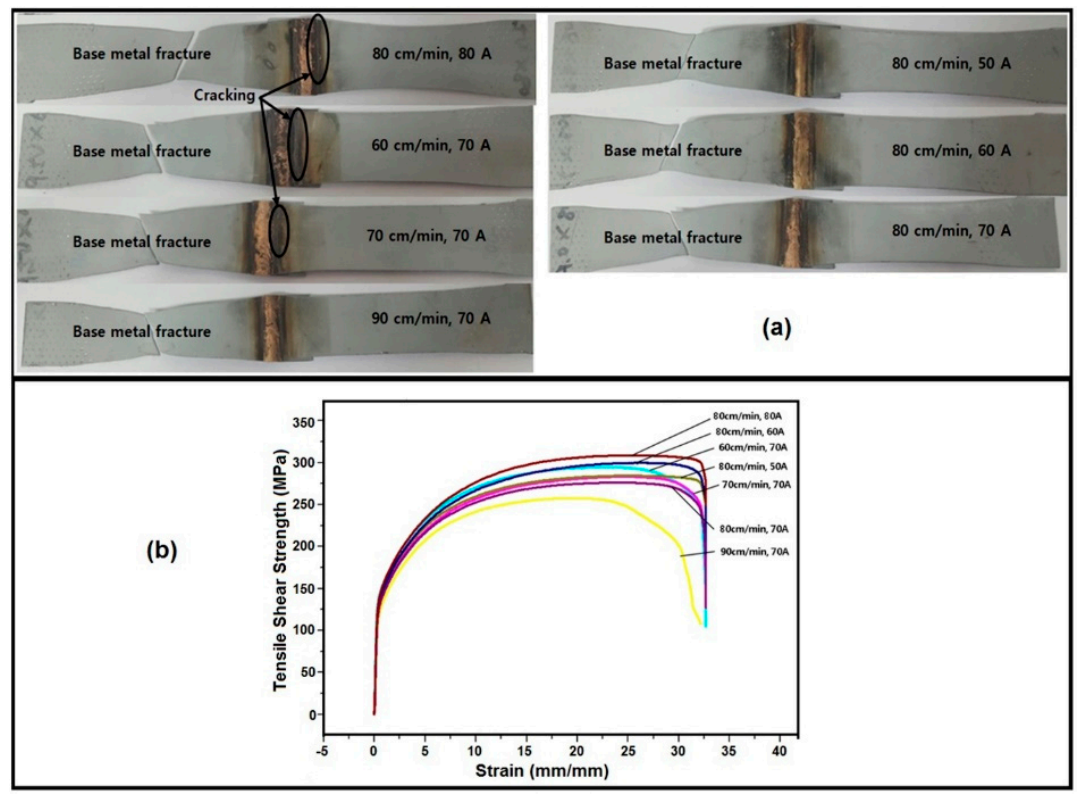

Figure 10. (a) Post-test photographs of the tensile samples, and (b) Tensile shear stress-strain curves of the various joints.

The UTS of the samples varies from (from 240 to $300 \mathrm{MPa}$ ), and a minute increment in elongation. Lowest UTS is obtained at $70 \mathrm{~A} / 90 \mathrm{~cm} / \mathrm{min}$ followed by $70 \mathrm{~A} / 80 \mathrm{~cm} / \mathrm{min}$ due to a lesser time available for the arc at high temperature. The UTS further decreases at lower arc current from $50 \mathrm{~A} / 80 \mathrm{~cm} / \mathrm{min}$ and increases slightly for lower brazing speeds $(70 \mathrm{~A} / 60 \mathrm{~cm} / \mathrm{min})$.

It can be noticed that the arc current and the brazing speed are interrelated to each other as arc current is directly proportional to the heat input while brazing speed is related inversely to the heat input. As the arc current increases and the brazing speed declines, the joint strength improves due to sufficient heat input. Tensile strength is maximum $(\approx 320 \mathrm{MPa})$ at brazing speeds of $80 \mathrm{~A} / 80 \mathrm{~cm} / \mathrm{min}$ followed by $60 \mathrm{~A} / 80 \mathrm{~cm} / \mathrm{min}$ due to a maximum penetration of base metal. This result is consistent with the results reported by $\mathrm{Li}$ and his co-workers for welding of galvanized steel sheets [31]. As shown in Figure 10a, base metal fracture occurs in all the samples. This signifies a higher joint strength over the base metal (EG) caused by the formation of $\mathrm{Fe}_{5} \mathrm{Si}_{3} \mathrm{IMCs}$.

\subsubsection{Strengthening Mechanism of Weld Joints}

The effective contribution to the various strengthening mechanisms operating in the weld joints can be expressed as:

$$
\sigma=\sigma_{\text {Hall-Petch }}+\sigma_{\text {dislocations }}+\sigma_{\text {precipitates }}+\sigma_{\text {solid solution }}
$$

where the various terms represent yield strength due to (A) Hall-Petch (grain boundary), (B) dislocations, (C) precipitates (Orowan), and (D) solid solution strengthening, respectively.

The various contributions (A-D) to the yield strength are given by:

$$
\text { (A): } \sigma_{\text {Hall-Petch }}=\sigma_{0}+k d^{-1 / 2}
$$

where $d$ is the grain size, and $\sigma_{0}$ is a constant related to the hindrance to motion of dislocations. Hall-Petch coefficient, $k=G \cdot b \theta . G=78$ and $66 \mathrm{GPa}$ for EG and fusion zone. Burger vector for fcc metals, $b=0.254 \mathrm{~nm}[33,34]$. The misorientation angle $\theta=3^{\circ}$ and $15^{\circ}$ for the base metal, and the fusion zone, respectively. The Hall-Petch contribution is given by:

$$
\sigma_{\text {Hall-Petch }}(\text { EG base metal })=59.4 d^{-1 / 2}
$$




$$
\begin{gathered}
\sigma_{\text {Hall-Petch }}(\text { fusion zone })=25.1 d^{-1 / 2} \\
\text { (B): } \sigma_{\text {dislocations }}=M \alpha G b \rho /^{1 / 2}
\end{gathered}
$$

Substituting $M \approx 3$ and $\alpha=0.3$ for fcc metal, $b=0.254 \mathrm{~nm}$, and $\rho$ the dislocation density $\approx 1.57 \times$ $10^{15} \mathrm{~m}^{-2}$ [35].

$$
\begin{gathered}
\sigma_{\text {dislocations }}(\text { fusion zone })=59.1 \mathrm{MPa} . \\
\sigma_{\text {dislocations }}(\text { base metal })=70.8 \mathrm{MPa} . \\
\left(\text { C) }: \sigma_{\text {precipitates }}=M \frac{0.4 G b}{\pi \sqrt{1-v}} \frac{\ln (2\langle r\rangle / b)}{\lambda}\right.
\end{gathered}
$$

where Poisson's ratio of steel matrix, $v=0.29$ [36], and $\langle r\rangle$ is the average radius of a circle for a spherical precipitate [37]:

$$
<r>^{2}=2 / 3 r^{2}
$$

and $\lambda$ inter precipitate spacing [38]:

$$
\lambda=2<r>\left((\pi / 4 f)^{1 / 2}-1\right)
$$

As there was no precipitation in EG base, the Orowan bypassing contribution is:

$$
\sigma_{\text {precipitate }}\left(\text { fusion zone) }=48.3 \mathrm{MPa} \text { and }(\mathrm{D}): \sigma_{\text {solid solution }}=A G \varepsilon^{4 / 3} \cdot C^{2 / 3}[35]\right.
$$

where $A$ is of the order of $0.1, C$ is the solute concentration, $C=0.45, G=78000 \mathrm{MPa}, \varepsilon$ is the lattice strain to overcome the size difference $(\mathrm{Mn}$ (atom radii $=161 \mathrm{pm}$ ) and $\mathrm{Fe}$ (atom radii $=156 \mathrm{pm}) \sim 3 \%$. Based on these variables, the $\sigma_{\text {solid solution }}$ of the fusion zone and base metal are 36.7 and $41.4 \mathrm{MPa}$. Therefore, according to equation (4), the total strength is equal to $303 \mathrm{MPa}$, which is higher than the base metal strength $(\approx 240 \mathrm{MPa})$ and hence base metal fracture is obtained in the samples. The predicted strength of EG lap joints shows a good correlation with the experimental data.

\section{Conclusions}

Heat input controlled by arc current and speed and current results in increased penetration of the base metal. Increase in arc current (50 to $70 \mathrm{~A}$ ) or a decrease in arc speed (70 to $60 \mathrm{~cm} / \mathrm{min}$ ) causes more fusion of EG steel and Cu-Si filler. The cross-section of the EG joint displays the formation of $\mathrm{Fe}_{5} \mathrm{Si}_{3}$ and $\mathrm{Fe}_{2} \mathrm{Si}$ intermetallic compounds. $\mathrm{Fe}_{2} \mathrm{Si}$ compounds exist on the base metal side. Microhardness of the joint is enhanced by the reinforced Fe-Si intermetallic particles into fusion zone and grain refining by the arc heating effect. In addition, microhardness is approximately $>90 \%$ hardness than that of the EG steel. Tensile shear tests indicate higher shear strength at the interface of the base metals (EG) and $\mathrm{CuSi}_{3}$ filler metal zone. The tensile fractured samples show a base metal fracture irrespective of brazing condition except minor cracks seen near edge of the bead brazed at $80 \mathrm{~cm} / \mathrm{min}-80 \mathrm{~A}, 60 \mathrm{~cm} / \mathrm{min}-70 \mathrm{~A}$, and $70 \mathrm{~cm} / \mathrm{min}-70 \mathrm{~A}$. The predicted strengthening mechanisms operated in the tensile welds support the experimental findings.

Author Contributions: J.P.J. provided the concept and facility for carrying out this work. S.J.L. performed the experiments, methodology and prepared original draft of this manuscript. A.S. analyzed the data and provided the mechanism of the brazed joint formation. D.H.J. performed formal analysis and editing of the manuscript. J.P.J. reviewed and recommended the final corrections. Finally, all authors read, checked and corrected the whole manuscript.

Funding: 2018 Research Fund of the University of Seoul.

Acknowledgments: This work was supported by the 2018 Research Fund of the University of Seoul.

Conflicts of Interest: The authors declare no conflict of interest. 


\section{References}

1. Lee, T.G.; Lee, H.D.; Lee, J.K. Development of the elastic modulus of 100 GPa casting alloys by nickel addition. Korean J. Met. Mater. 2017, 55, 845-852.

2. Kim, J.I.; Jin, S.W.; Jung, J.; Sung, H.M.; Jeong, H.J.; Park, S.; Park, J.W.; Han, H.N. Growth behavior of intermetallic compound in dissimilar Al-Cu joints under direct current. Korean J. Met. Mater. 2017, 55, 372-378.

3. Hong, M.S.; Park, I.J.; Kim, J.G. Alloying effect of copper concentration on the localized corrosion of aluminum alloy for heat exchanger tube. Met. Mater. Int. 2017, 23, 708-714. [CrossRef]

4. Tsao, L.C.; Weng, W.P.; Cheng, M.D.; Tsao, C.W.; Chuang, T.H. Brazeability of a 3003 Aluminum alloy with Al-Si-Cu-based filler metals. J. Mater. Eng. Perform. 2002, 11, 360-364. [CrossRef]

5. Mucha, J.; Kascak, L.; Spisak, E. Joining the car-body sheets using clinching process with various thickness and mechanical property arrangements. Arch. Civ. Mech. Eng. 2011, 11, 135-148. [CrossRef]

6. Katundi, D.; Tosun-Bayraktar, A.; Bayraktar, E.; Toueix, D. Corrosion behavior of the welded steel sheets used in automotive industry. JAMME 2010, 38, 146-153.

7. Gullino, A.; Matteis, P.; D'Aiuto, F. Review of aluminum-To-steel welding technologies for car-body applications. Metals 2019, 9, 315. [CrossRef]

8. Sharma, A.; Roh, M.H.; Jung, D.H.; Jung, J.P. Effect of $\mathrm{ZrO} 2$ nanoparticles on the ... Al brazing applications. Metall. Mater. Trans. A 2016, 47, 510-521. [CrossRef]

9. Sierra, G.; Peyre, P.; Beaume, F.D.; Stuart, D.; Fras, G. Galvanised steel to aluminium joining by laser and GTAW processes. Mater. Charact. 2008, 59, 1705-1715. [CrossRef]

10. Qin, G.; Su, Y.; Meng, X.; Fu, B. Numerical simulation on MIG arc brazing-fusion welding of aluminum alloy to galvanized steel plate. Int. J. Adv. Manuf. Technol. 2015, 78, 1917-1925. [CrossRef]

11. Monika; Chauhan, J. A review paper on gas metal arc welding (GMAW) of mild steel 1018 by using taguchi technique. IJCESR 2017, 4, 57-62.

12. Kim, Y.; Park, K.; Kwak, S. A review of arc brazing process and its application in automotive applications. Int. J. Mech. Eng. Robot. Res. 2016, 5, 246-250. [CrossRef]

13. Mallick, P.K. Joining for lightweight vehicles. In Materials, Design and Manufacturing for Lightweight Vehicles; Mallick, P.K., Ed.; Woodhead Publishing: Cambridge, UK, 2010; pp. 275-308.

14. Sharma, A.; Lee, S.J.; Choi, D.Y.; Jung, J.P. Effect of brazing current and speed on the bead characteristics, microstructure, and mechanical properties of the arc brazed galvanized steel sheets. J. Mater. Proc. Technol. 2017, 249, 212. [CrossRef]

15. Karadeniz, E.; Ozsarac, U.; Yildiz, C. The effect of process parameters on penetration in gas metal arc welding processes. Mater. Des. 2007, 28, 649-656. [CrossRef]

16. Singh, L.; Singh, D.; Singh, P. A review: Parametric effect on mechanical properties and weld bead geometry of aluminium alloy in GTAW. IOSR-JMCE 2013, 6, 24-30. [CrossRef]

17. Yang, S.L.; Kovacevic, R. Welding of galvanized dual-phase 980 steel in a gap-free lap joint configuration. Weld. Res. 2009, 88, 168s-178s.

18. Kai, M.; Zhishui, Y.; Peilei, Z.; Yunlong, L.; Hua, Y.; Chonggui, L.; Xiaopeng, L. Influence of wire feeding speed on laser brazing zinc-coated steel with Cu-based filler metal. Int. J. Adv. Manuf. Technol. 2015, 76, 1333-1342. [CrossRef]

19. Funderburk, R.S. A look to heat input: Key concepts in welding engineering. In Weld. Innov; Miller, D.K., Funderburk, R.S., Eds.; The James F Lincoln Arc Welding Foundation: Cleveland, OH, USA, 1999; vol. XVI, pp. 8-11.

20. Japanese Industrial Standards. JIS Z 31361999 Japanese Industrial Standard for Tension Shear Tests; Japanese Standards Association: Tokio, Japan, 1999.

21. Sharma, A.; Roh, M.H.; Jung, J.P. Effect of $\mathrm{La}_{2} \mathrm{O}_{3}$ nanoparticles on the brazeability, microstructure, and mechanical properties of Al-11Si-20Cu alloy. J. Mater. Eng. Perform. 2016, 25, 3538-3545. [CrossRef]

22. Sharma, A.; Lim, D.U.; Jung, J.P. Microstructure and brazeability of SiC nanoparticles reinforced Al-9Si -20Cu produced by induction melting. Mater. Sci. Technol. 2016, 32, 773-779. [CrossRef]

23. Omajene, J.; Martikainen, J.; Kah, P. Effect of welding parameters on weld bead shape for welds done underwater. IJMEA 2014, 2, 128-134. [CrossRef] 
24. Ghazvinloo, H.R.; Raouf, A.H.; Shadfar, N. Effect of arc voltage, welding current and welding speed on fatigue life, impact energy and bead penetration of AA6061 joints produced by robotic MIG welding. Indian J. Sci. Technol. 2010, 3, 974.

25. Schmidt, M.; Otto, A.; Kläger, C. Analysis of YAG laser lap-welding of zinc coated steel sheets. CIRP Ann. 2008, 57, 213-216. [CrossRef]

26. Kimura, S.; Takemura, S.; Mizutani, M.; Katayama, S. Laser brazing phenomena of galvanized steel and pit formation mechanism. In Proceedings of the 25th International Congress on Applications of Laser \& Electro Optics, Scottsdale, AZ, USA, 30 October-2 November 2006; pp. 346-354.

27. Reimann, W.; Pfriem, S.; Hammer, T.; Päthe, D.; Ungers, M.; Dilger, K. Influence of different zinc coatings on laser brazing of galvanized steel. J. Mater. Proc. Technol. 2017, 239, 75-82. [CrossRef]

28. Ungers, M.; Fecker, D.; Frank, S.; Donst, D.; Märgner, V.; Abels, P.; Kaierle, S. In-situ quality monitoring during laser brazing. Phys. Procedia 2010, 5, 493-503. [CrossRef]

29. Gordon, A.P.; Mcdowell, D.L. Numerical simulation of time-dependent fracture of graded bimaterial metallic interfaces. Int. J. Frac. 2004, 126, 321-344. [CrossRef]

30. Li, R.F.; Yu, Z.S.; Qi, K.; Zhou, F.M.; Wu, M.F.; Yu, C. Growth mechanisms of interfacial compounds in arc brazed galvanised steel joints with $\mathrm{Cu}_{97} \mathrm{Si}_{3}$ filler. Mater. Sci. Technol. 2005, 21, 483-487. [CrossRef]

31. Li, L.Q.; Feng, X.S.; Chen, Y.B. Influence of laser energy input mode on joint interface characteristics in laser brazing with Cu-base filler metal. Nonferrous Met. Soc. China 2008, 18, 1065-1070. [CrossRef]

32. Luo, S.B.; Wang, W.L.; Xia, Z.C.; Wei, B.B. Liquid phase separation and subsequent dendritic solidification of ternary $\mathrm{Fe}_{35} \mathrm{Cu}_{35} \mathrm{Si}_{30}$ alloy. Trans. Nonferrous Met. Soc. China 2016, 26, 2762-2769. [CrossRef]

33. Abson, D.J.; Jonas, J.J. The Hall-Petch relation and high-temperature subgrains. Met. Sci. J. 1970, 4, $24-28$. [CrossRef]

34. Krauss, G. Martensite in steel: Strength and structure. Mater. Sci. Eng. A 1999, 273, 40-57. [CrossRef]

35. Kim, J.G.; Enikeev, N.A.; Seol, J.B.; Abramova, M.M.; Karavaeva, M.V.; Valiev, R.Z.; Park, C.G.; Kim, H.S. Superior strength and multiple strengthening mechanisms in nanocrystalline TWIP steel. Sci. Rep. 2018, 8, 11200. [CrossRef] [PubMed]

36. Bringas, J.E.; Lamb, S. CASTI Handbook of Stainless Steels \& Nickel Alloys; CASTI Publishing INC: Edmonton, AB, Canada, 2002.

37. Argon, A.S.; Egon, E. Orowan, Physics of Strength and Plasticity; MIT Press: Cambridge, MA, USA, 1969.

38. Kelly, A. Strengthening Methods in Crystals; Elsevier Publishing Company: Amsterdam, The Netherlands, 1971.

(C) 2019 by the authors. Licensee MDPI, Basel, Switzerland. This article is an open access article distributed under the terms and conditions of the Creative Commons Attribution (CC BY) license (http://creativecommons.org/licenses/by/4.0/). 